\title{
ARTICLE
}

\section{EMPLOYEE TRAINING IN SMALL AND MEDIUM-SIZED ENTERPRISES IN MONGOLIA}

Tuul O.* and Shao Jian Bing

Business School, University of Liaoning, Shenyang, China

\begin{abstract}
In many developed and developing countries, small and medium-sized enterprises (SMEs) play a significantrole in their development. All researches show that globally, SMEs account for more than 90 percent of all business activities and earlier studies have established that SMEs have a critical role in contributing to a country's economic growth [2] such as reducing poverty and unemployment,and creating employment opportunities. In addition, they contribute to reducing inequitable income distribution, enhancing competitiveness of enterprises, as well as promoting social stability. Therefore, the development of SMEs represents theprimary goal of every modern economy. There are many factors that influence the development of SMEs andone of the most important among them is the human resource management practice, especially employees' training. Therefore, the main aim of our study is to examine the level of awareness of the training and development (T\&D) policy among owners or managers of SMEs, their attitude and organisational support towards training and to analyse the training-related problems encountered by SMEs within the context of Mongolia.
\end{abstract}

Keywords: Small and medium-sized enterprises (SMEs); human resource management (HRM); employee training; training and development $(T \& D)$;

\section{INTRODUCTION}

Over the years, the development of SMEs has had a greatimpact on social growth of all countries across the world. It is understood that SMEs are conducive to the stabilisation of the country's monetary situation, increase in technological innovation, creation of employment opportunities, growth in industrial productionand industrial diversification. In developing countries like Mongolia, SMEs play an important role in economic growth while reducing poverty and unemployment. Additionally, the development of SMEs helps reduce income inequality, maintain social stability and promote the development of the private sector.

In 1990, Mongolia made atransition from centralised planned economy to ademocratic parliamentary system with free market. This transition brought about many positive changes in the country, such as multi-party 
election, democracy, land privatization, market economy and international cooperation. The country also started restructuring the state-owned enterprises, mainly through privatization. At the same time, SMEs began their own specific historical development also from 1991. Today, SMEs make significant contribution to the Mongolian economy by employing around $67 \%$ of the national workforce, producing $20 \%$ of the GDP, accounting for $2.3 \%$ of exports and $19 \%$ of enterprise income tax. At the end of 2018, although 167,123 businesses were officially registered, according to the National Statistics Office, only a little more than half of them or 85,488 businesses have been active.72,692 or $85 \%$ of all businesses employ 1 to 9 staff, 6,259 or $7.3 \%$ of the businesses have 10 to 19 workers, 4,078 or $4.8 \%$ of the businesses have 20 to 49 staff members and only 2,459 or $2.9 \%$ of all the businesses in the country employ 50 and more workers(National Statistics Office, 2018).39.9\% the officially active businesses are engaged in trade and $39.1 \%$ in the services sector, $8.7 \%$ of them are in the manufacturing sector, $7.8 \%$ in the construction industry and only $4.8 \%$ in the agriculture sector.

The definition of SMEs by sector, number of workers and annual income, according to the Mongolian Law on SMEs, is given in Table $1[12,14]$ :

Table 1. Definition of SMEs in Mongolia

\begin{tabular}{|l|l|c|c|}
\hline \multicolumn{1}{|c|}{ Category } & \multicolumn{1}{c|}{ Sector } & $\begin{array}{c}\text { Number of } \\
\text { employees }\end{array}$ & Annual revenue in MNT \\
\hline Microenterprises & Manufacturing and & $\geq 19$ & $\geq 250$ million \\
& service & $\geq 9$ & $\geq 250$ million \\
\hline \multirow{3}{*}{ Small enterprises } & Trade/services, & $\geq 9$ & $\geq 250$ billion \\
& manufacturing and & $\geq 19$ & $\geq 250$ billion \\
& services & $\geq 49$ & $\geq 1.0$ billion \\
\hline \multirow{3}{*}{ Medium enterprises } & Wholesale trade, & $\geq 149$ & $\geq 1.5$ billion \\
& retail trade and & $\geq 199$ & $\geq 1.5$ billion \\
& manufacturing & $\geq 199$ & $\geq 1.5$ billion \\
\hline
\end{tabular}

Source: Law on SMEs, 2007

The Mongolian government has adopted targeted policy tools to promote SMEs as part of economic development strategy, for example,the Law on SMEs was passed in 2007. The Government also established a SME Agency in 2008 responsible for, implementing related policies and an SME Fund in 2009. Furthermore, the Government, in order to promote SMEs development and improve the businesses climate, announced 2009 as the Year of Supporting Industrial Production; 2010 as the Year of Improving Business Environment; 2011 as a Year of Supporting Employment; and 2012 as the Year of Supporting Households' Development. In 2014, an SME Development Programme (2014-2016) was launched, under which 2016 was announced as the Year of "Promoting Domestic Production and Sales" and policy actions were taken to enhance SME competitiveness and to create employment. The Bank of Mongolia annually conducts a nationwide (Ulaanbaatar and 21 aimags) SME survey in order to have a better understanding of the business characteristics, their current development status, financial access and the challenges encountered by SMEs [3,21].

\section{Literature review}

Many Human Resource Management (HRM) literature define Training and Development(T\&D) as themain tool for improving and enhancing organizational performance. Many studies have been conducted earlier on employee T\&D. According to M. Armstrong (2001), training is the formal and systematic modification of 
behaviour through learning which occurs as a result of education, instruction, development, and planned experience. According to Thomas Gordon (1992), T\&D is a type of activity which is planned systematically and it results in the enhanced level of skills, knowledge, and competency that are necessary to perform work effectively and efficiently. Training can be used to improve or develop employees' knowledge, skills, attitudes, and other work-related performance. Tahir, A \& Sajjad, S (2013) tested that effective needs assessment, training program evaluation, investment, education needs, provide flexibility training, training, motivation, social support, knowledge transfer, social support, leadership qualities, training opportunities, the knowledge of the trainer, training effect, know your customer policy skills, negotiation skills and comprehensive quality management, behaviour and emotional intelligence have a significant or insignificant impact on employees' job performance.

And their findings showed that that proper needs assessment, effectiveness of training programme, investment in training, and provision of training all significantly affect employees' job performance [20].

It is important for any organisation to design the training plan very carefully (Armstrong, 2000). Since the roles and responsibilities of employees shift rapidly in small firms, it follows that some sort of T\&D concerning new roles and responsibilities is vital to the success of the employee and the business[4]. There are many types of training that can be offered to SME employees. Choosing the right type of training can ensure that the employees possess the right skills for the business, and the training programme needs to be continuously updated with due consideration of the best and new HR practices [24]. According to researchers such as Kulkarni (2013) and et al,there are two broad types of training available to businesses: on-the-job and off-the-job techniques[10].

On the job training helps employees to get a proper knowledge of their job in a better way (Deming, 1982). It is delivered to employees while they perform their regular jobs. In this way, they do not lose time while they are learning at the same time. On-the-job techniques include orientations, job instruction training, apprenticeships, internships and assistantships, job rotation and coaching. Off-the-job techniques include lectures, special study, films, television conferences or discussions, case studies, role-playing, simulation, programmed instruction and laboratory training $[5,7,11]$. Most of these techniques can be used by small businesses although, some may be too costly[18].

Despite the growing importance of SME research during the last decade, little attention has been given to the study of T\&D practices in SMEs[5].Not only do SMEs themselves pay less attention to training, but the issue of T\&D in SMEs has also been relatively neglected by academics [8,9] (Pettigrew et al., 1990).

Human resource training is a very challenging task for SMEs (Williamson, Cable, \& Aldrich, 2002).Compared with large enterprises, formal training resources are limited in small enterprises, which train employees through trade unions, short-term seminars and family training[13].

As regards Mongolia, not many studies on SMEs have been conducted either by researchers, HRM organisations or other research institutions since 1991. For instance, the Bank of Mongolia annually conducts a nationwide (Ulaanbaatar and 21 aimags) SMEs survey in order to have a better understanding of the business characteristics, their current development status, financial access and the challenges faced by SMEs. According to the Bank of Mongolia survey, social and political conditions, macroeconomy, financing, legal and institutional conditions are the most challenging factors for SMEs. Moreover, some researches, such as theoretical issues of SME (Norjvaanching, Bet. al), SME management and organisational management of SMEs (Batbayar, 2008, 2009),(Byambasüren, D., Dorj, T.,et. al), production management (Narantshüü L \& Jandersüren B, 2012 and 
et al), current situation and future prospects for SMEs (Badarch, D. \& Dolgorsuren, Ts., et. al), technology and business incubators of SME (Oyuntsetseg, L., Byambasüren, Ya., Ganbaatar, Kh., Monkhjin), competitive advantages of SME (Shürchuluu, P. et. al) and the returns of SME (Lkhagvasuren\&Huo, 2018) have been conducted[14].

For HRM,some researchers including Batkhurel, G. (2012), Dorj, T., Tsetsegmaa, Ts. (2003, 2014), Tserendor,j T., Purevdava,Kh. (2015) and so on have studied the role of HRM [17,22] and they have investigated the theoretical aspects of managing human resources in their works. Batkhishig, I., Myagmarsuren, D. (2016) and others have studied HRM in SMEs, while Zolzaya \& Zhou(2014) and Bayartsetseg, Ts. (2014) have investigated some problems of human resource recruitment and selection at Mongolian SMEs. Despite the increasing influence of organisations on employee training, Mongolian literature on human resource training is still limited.

From the above literature review, it can be summarised that the development of SMEs does not have a long history, meanwhile, human resource management practice at SMEs is still in the earlystage of its development,

\section{MATERIALS AND METHODS}

In order to accomplish the goal of our research, a random sampling method was used. Accordingly, data was collected using a questionnaire. The questionnaire is divided into four parts, the first part contains the demographical profile of the respondents including, gender, age etc. The second part includes abackground check. The third part consists of questions regarding employee's since the existing research mainly focuses on SME financing and management. There still is no sufficient literature on the subject of HRM and employee training in SMEs in Mongolia.

\section{Aim of the study and research questions}

HRM has been increasingly giving greater priority to the issue of training. It has become a very important, albeit costly activity [1] for any business organisation, specially SMEs. Therefore, the aim of this study is to analyse the current situation of employee training at SMEs, examine the attitude of the owners/ managers and organisational support towards training and find out the problems existing in employee training at SMEs in the context of Mongolia.

Based on the aim of our study, we have investigated and sought answers to the following research questions:

1. Do SMEs have any training policy and programme?

2. What type of training do SMEs provide their employees?

3. How can the SMEs provide training to meet employees' needs?

4. Are there any training-related challenges faced by SMEs?

training using the interval scale with fivepoints from strongly disagree to strongly agree. The last and the fourth part includes open-ended questions which were used to help check the validity of the data collected through questionnaires. The questionnaire was conducted between November 2018 and February 2019 involving 209 SMEs in Mongolia.

\section{RESULTS AND ANALYSIS}

We have summarised the response to the questionnaires and have attempted to provide a detailed explanation of the research findings. The profile of the sample respondents of this 
study is shown in Table 2. There were 111 female respondents $(53.1 \%)$ and 98 male respondents (46.9\%). For respondents' age, respondents between the age of 26 and 45 years accounted for $72.3 \%$ of all the respondents. $20.6 \%$ of respondents were in the age category from 46 to 55 years old and $10 \%$ of them were over 55 years old.

Table 1 shows that $33.5 \%$ of respondents had working experience of less than 5 years, $54.1 \%$ of the respondents had been working for 5 to 10 years, followed by $11.0 \%$ of the respondents, whose working experience

Table 2.Demographic characteristics of the respondents $\%(N=209)$

\begin{tabular}{|c|c|c|c|}
\hline \multirow{2}{*}{\multicolumn{2}{|c|}{ Respondents }} & \multirow{3}{*}{$\begin{array}{c}\text { Frequency } \\
98 \\
\end{array}$} & \multirow{3}{*}{$\begin{array}{c}\text { Percent } \\
46.9\end{array}$} \\
\hline & & & \\
\hline \multirow{2}{*}{ Gender } & Male & & \\
\hline & Female & 111 & 53.1 \\
\hline \multirow{5}{*}{ Age } & $<24$ & 3 & 1.4 \\
\hline & $25-35$ & 34 & 16.3 \\
\hline & $36-45$ & 108 & 51.7 \\
\hline & $46-55$ & 43 & 20.6 \\
\hline & $55<$ & 21 & 10.0 \\
\hline \multirow{4}{*}{ Year of work experience } & $<5$ & 70 & 33.5 \\
\hline & $6-10$ & 113 & 54.1 \\
\hline & $11-15$ & 23 & 11.0 \\
\hline & $16<$ & 3 & 1.4 \\
\hline \multirow{3}{*}{$\begin{array}{l}\text { Respondents'positionsin the } \\
\text { company }\end{array}$} & Owner/director & 81 & 38.8 \\
\hline & General manager & 116 & 55.5 \\
\hline & Others & 12 & 5.7 \\
\hline
\end{tabular}

Table 3 shows that $67 \%$ of the firms are engaged in retail trade and services sector, whereas $18 \%$ operates in the manufacturing sector and $10 \%$ in the construction and $1.4 \%$ in the mining and $3.3 \%$ in other sectors of the economy. As regards the years of their operation, $66.1 \%$ of the firms have been operating for $6-10$ years, $18.1 \%$ for less than 5 years, $12.6 \%$ for $11-15$ years, $2.4 \%$ for ranged from 11 to 20 years and $16.5 \%$ of the respondents had work experience of 21 to 30 years. Lastly, $3 \%$ of the respondents had work experience of 16 and more years. From this analysis, it appears that the majority of the respondents have a low to medium number of years of experience working at SMEs.

With regards to the current position of respondents, a majority of them or $55.5 \%$ of the sampled respondents were general managers, $38.8 \%$ were owners or directors and only $5.7 \%$ of the other respondents were working as accountants and organisers. 
Table 3.Firm background $(N=209)$

\begin{tabular}{|c|l|c|c|}
\hline \multicolumn{2}{|c|}{ Participants } & Frequency & Percent \\
\hline \multirow{4}{*}{ Business activity } & Service & 38 & 37.3 \\
\cline { 2 - 4 } & Retail and trade & 62 & 29.7 \\
\cline { 2 - 4 } & Industry & 78 & 18.2 \\
\cline { 2 - 4 } & Construction & 21 & 10.0 \\
\cline { 2 - 4 } & Mining & 3 & 1.4 \\
\cline { 2 - 4 } & Other & 7 & 3.3 \\
\hline \multirow{5}{*}{ Yearsof operation } & $<5$ & 44 & 18.1 \\
\cline { 2 - 4 } & $6-10$ & 127 & 66.1 \\
\cline { 2 - 4 } & $11-15$ & 34 & 12.6 \\
\cline { 2 - 4 } & $16-20$ & 3 & 2.4 \\
\cline { 2 - 4 } & $21<$ & 1 & 0.8 \\
\hline \multirow{5}{*}{ Geographical location } & UB & 135 & 64.6 \\
\cline { 2 - 4 } & Rural provinces & 74 & 35.4 \\
\hline \multirow{5}{*}{ Total number of employees } & $1-9$ & 116 & 55.5 \\
\cline { 2 - 4 } & $10-19$ & 69 & 33.0 \\
\cline { 2 - 4 } & $20-49$ & 21 & 10.0 \\
\cline { 2 - 4 } & $50-100$ & 3 & 1.4 \\
\hline
\end{tabular}

Table 4 is aimed at finding out whether firms have a training and development programme and a plan, and whether it is updated regularly or not, in addition to examining if the training budget is allocated.The results indicate that firms have a training programme and plan (Mean=3.56), the training programme is updated regularly (Mean=3.20), the training budget is included in the firm's annual budget $($ Mean $=3.53)$. Firms have a training team $($ Mean $=2.37)$.

It is clear from the above resultas well as through open-ended questions that even though most of SMEs have a training policy and programme, it appears that the understanding of training concept is insufficient, the objective of the training is not clear, as well as the implementation of the training programme has not been carried out in a proper manner. In addition, most of the respondents agree that focus is given to the existence ofthe training team and most of the firms do not concentrate on the training programme and plan.

Table 5 below represents the employees' training needs. It was also discovered that training is designed to improve employees' new knowledge and skills. (Mean=4.06), prevent workplace accident (Mean= 3.99), enhance employees' capability (Mean $=3.92$ ) and employees' efficiency (Mean $=3.56$ ).

From the below results, respondents either strongly agree or simply agree that most ofthe training programmeis designed to enhance employees' professional knowledge and skills, and workplace safety. 
Table 4. Descriptive statistics of training and development policy

\begin{tabular}{|c|l|c|c|c|c|c|c|c|}
\hline \multirow{2}{*}{ № } & \multicolumn{1}{|c|}{ Items } & Mean & Medium & $\begin{array}{c}\text { Std. De- } \\
\text { viation }\end{array}$ & \multicolumn{2}{|c|}{ Skewed } & \multicolumn{2}{|c|}{ Kurtosis } \\
\cline { 2 - 9 } & Statistic & Statistic & Statistic & Statistic & $\begin{array}{c}\text { Std. } \\
\text { Error }\end{array}$ & Statistic & $\begin{array}{c}\text { Std. } \\
\text { Error }\end{array}$ \\
\hline 1 & $\begin{array}{l}\text { We have a training } \\
\text { programme and a } \\
\text { plan }\end{array}$ & 3.56 & 4.00 & .859 & -.762 & .168 & 1.104 & .335 \\
\hline 2 & $\begin{array}{l}\text { We update our } \\
\text { training programme } \\
\text { every year }\end{array}$ & 3.20 & 3.00 & .801 & -.210 & .168 & .643 & .335 \\
\hline 3 & $\begin{array}{l}\text { We have a training } \\
\text { team }\end{array}$ & 2.37 & 2.00 & 1.030 & .519 & .168 & -.293 & .335 \\
\hline 4 & $\begin{array}{l}\text { We have adequately } \\
\text { allocated the budget } \\
\text { for training }\end{array}$ & 3.53 & 4.00 & .855 & -.176 & .168 & .073 & .335 \\
\hline
\end{tabular}

Table 5. Training needs

\begin{tabular}{|c|l|c|c|c|c|c|c|c|}
\hline \multirow{2}{*}{ № } & \multicolumn{1}{|c|}{ Items } & Mean & Medium & $\begin{array}{c}\text { Std. De- } \\
\text { viation }\end{array}$ & \multicolumn{2}{|c|}{ Skewed } & \multicolumn{2}{|c|}{ Kurtosis } \\
\cline { 2 - 9 } 1 & Statistic & Statistic & Statistic & Statistic & $\begin{array}{c}\text { Std. } \\
\text { Error }\end{array}$ & Statistic & $\begin{array}{c}\text { Std. } \\
\text { Error }\end{array}$ \\
\hline & $\begin{array}{l}\text { Training is designed } \\
\text { to improve employ- } \\
\text { ees' knowledge and } \\
\text { skills }\end{array}$ & 4.06 & 4.00 & .651 & -.378 & .168 & .488 & .335 \\
\hline 2 & $\begin{array}{l}\text { Training is designed } \\
\text { to prevent workplace } \\
\text { accidents }\end{array}$ & 3.99 & 4.00 & .750 & -.529 & .168 & .622 & .335 \\
\hline 3 & $\begin{array}{l}\text { Training is designed } \\
\text { to improve employ- } \\
\text { ee capability }\end{array}$ & 3.92 & 4.00 & .848 & -.990 & .168 & 1.629 & .335 \\
\hline 4 & $\begin{array}{l}\text { Training is designed } \\
\text { to enhance employee } \\
\text { efficiency }\end{array}$ & 3.56 & 4.00 & .789 & -.035 & .168 & -.107 & .335 \\
\hline
\end{tabular}

Choosing the appropriate type of training is essential for better training outcomes. Table 6 is aimed at identifying the types of training thatare provided to the employees.

According to the survey results, it has been found that most SMEs encourage their employees to participate in orientation (Mean $=4.00$ ), encourage employees to attend lecture (classroom training is important (Mean $=2.87$ ), believe that long-term training is useful for their employees (Mean =4.09), and computer- based training is useful for employees (Mean $=2.64)$.

Lectures, workshops, computer-based training are considered as off-job training and orientation, while internship and assistantship are considered as on-job training.As a result, wehave found that due to the special features of SMEs, they prefer on-job training to off-job training and prefer short-term to long-term training. 
Table 6. Types of trainingsand development methods

\begin{tabular}{|c|l|c|c|c|c|c|c|c|}
\hline \multirow{2}{*}{ № } & \multicolumn{1}{|c|}{ Items } & Mean & Medium & $\begin{array}{c}\text { Std. De- } \\
\text { viation }\end{array}$ & \multicolumn{2}{|c|}{ Skewed } & \multicolumn{2}{|c|}{ Kurtosis } \\
\cline { 2 - 9 } 1 & Statistic & Statistic & Statistic & Statistic & $\begin{array}{c}\text { Std. } \\
\text { Error }\end{array}$ & Statistic & $\begin{array}{c}\text { Std. } \\
\text { Error }\end{array}$ \\
\hline $\begin{array}{l}\text { We encourage our em- } \\
\text { ployees to participate } \\
\text { in orientation }\end{array}$ & 4.00 & 4.00 & .788 & -.826 & .168 & 1.374 & .335 \\
\hline $\begin{array}{l}\text { We encourage our em- } \\
\text { ployees to participate } \\
\text { in a seminars, lectures } \\
\text { (workshop training is } \\
\text { important) }\end{array}$ & 2.87 & 3.00 & .994 & .025 & .168 & -.372 & .335 \\
\hline 3 & $\begin{array}{l}\text { Internships and as- } \\
\text { sistantships are useful } \\
\text { for our employees }\end{array}$ & 4.09 & 4.00 & .594 & -.166 & .168 & .384 & .335 \\
\hline 4 & $\begin{array}{l}\text { Computer-based train- } \\
\text { ing is useful for our } \\
\text { employees }\end{array}$ & 2.64 & 3.00 & .839 & -.167 & .168 & -.278 & .335 \\
\hline
\end{tabular}

The questions in Table 7 are associated with the challenges of training, including employee turnover (Mean=4.14), lack of and inadequate funds (Mean=4.06), shortage of employee experience and foreign language skills (Mean=3.98), and the poor quality of training facilities (Mean=3.91).It has been observed that the highest number of respondents either strongly agreed or agreed that employee turnover and cost of training faced by SMEs were yet the biggest challenges.

From the above results and through openended questions, we have found out that due to the poor reputation of SMEs and their low wages, employee turnover rate is relatively high, and the employees, who are trained, usually work stably for only 3-5 years. Moreover, SMEs do not have enough training facilities and equipment to provide adequate training for their employees.

Table 7. Challenges of training and development

\begin{tabular}{|c|l|c|c|c|c|c|c|c|}
\hline \multirow{2}{*}{ № } & \multicolumn{1}{|c|}{ Items } & Mean & Medium & $\begin{array}{c}\text { Std. De- } \\
\text { viation }\end{array}$ & \multicolumn{2}{|c|}{ Skewed } & \multicolumn{2}{|c|}{ Kurtosis } \\
\cline { 2 - 9 } & Statistic & Statistic & Statistic & Statistic & $\begin{array}{c}\text { Std. } \\
\text { Error }\end{array}$ & Statistic & $\begin{array}{c}\text { Std. } \\
\text { Error }\end{array}$ \\
\hline 1 & $\begin{array}{l}\text { Lack of and } \\
\text { inadequate funds }\end{array}$ & 4.06 & 4.00 & .655 & -.163 & .168 & -.295 & .335 \\
\hline & $\begin{array}{l}\text { Shortage of } \\
\text { employee } \\
\text { experience and } \\
\text { foreign language } \\
\text { skills }\end{array}$ & 3.98 & 4.00 & .778 & -.523 & .168 & .059 & .335 \\
\hline 3 & $\begin{array}{l}\text { The poor quality } \\
\text { of facilities }\end{array}$ & 3.91 & 4.00 & .798 & -.417 & .168 & -.200 & .335 \\
\hline 4 & $\begin{array}{l}\text { Employee } \\
\text { turnover }\end{array}$ & 4.14 & 4.00 & .724 & -.677 & .168 & .592 & .335 \\
\hline
\end{tabular}




\section{RESULTS AND DISCUSSION}

For Mongolia, the history of SME development is not long, and the level of awareness of HRM is not high either. So, the HR policies are imperfect and directors and managers, who are infact the owners the company do not, on the whole, have professional management experience.

What's more SMEs, as a whole, do not have training departments and a well-defined training system as such, indicating that they do not pay attention to training as they normally should. In addition, due to the special features of SMEs such as the size, limited resources, lack of skilled employees, performance etc., they face many challenges like high employee turnover, shortage of funds, lack of facilities, inferior training policy and so on.

\section{Limitations}

Firstly, this is a small sample study, only focusing on the employee T\&D at SMEs in Mongolia.

Secondly, the questionnaire in our study was mostly carried out with the owners or managers of SMEs in the Mongolian context.

\section{CONCLUSIONS}

SMEs are important contributors to economic development in all developed and developing countres. They have a potentially important role in creating jobs, reducing inequitable income distribution, enhancing the competitiveness of enterprises and supporting social stability. Moreover, for any SME, employee T\&D is an important tool to improve performance, capacity, productivity

and sustain competitive advantage. Therefore, SME owners/managers need to utilize T\&D to improve or develop employees' knowledge, skills, attitudes, and other work-related performance.

From the findings, we also discovered that in recent years, there is the emerging importance of research on SME and HRM practices especially employee training.

\section{REFERENCES}

[1] Abston, K.A., Vuong, J. (2017). Training and Development: A Live Case Project. Developments in Business Simulation and Experiential Learning. (44).

[2] Arafat, M.A., Ahmed, E. (2012). Managing Human Resources in Small and Medium Enterprises (SMEs) in Developing Countries: A Research Agenda for Bangladesh SMEs. pp. 215-219. DOI: 10.7763/IPEDR. (55). 43.

[3] Bank of Mongolia. (2016). Research of Mongolian Small and Medium Enterprises. Ulaanbaatar.

[4] Cardona, M.S., Stevens C.E. (2004). Managing Human Resources in Small Organisations: What Do We Know? Human Resource Management Review. (14), pp. 295-323.

[5] Chandrakumara,P. (2013). Human Resources Management Practices in Small and Medium Enterprises in Two Emerging Economies in Asia: Indonesia and South Korea. Annual SEAANZ Conference.pp. 1-15.

[6] Chen, W. (2013). Study on the Problems in the Employee Trainingof SME and the Countermeasures. 3rd International Conference on Education and Education Management. pp. 37-40.

[7] Duy, N.K., Oanh, N.T.H. (2015). Impact Evaluation of Training on Productivity of the Small and Medium Enterprises in Vietnam. Asian Social Science. (1)pp.10, 39-55. http:// 
dx.doi.org/10.5539/ass.v11n10p39.

[8] Gamage, A., Sadoi, Y. (2008). Determinants of Training and Development Practices in SMEs: A Case of Japanese Manufacturing Firms. Sri Lankan Journal of Human Resource Management. (2)1.

[9] Gamage, P., Imbulana, L. (2014). Training and Development and Performance of Employees: Evidence from Sri Lanka Telecom. International Journal of Marketing, Financial Services \& Management Research. 2, pp. 12-24.

[10] Kulkarni, P. P. (2013). A Literature Review on Training \&Development and Quality of Work Life. International Refereed Research Journal.www.researchersworld.com.

[11] Kum, F.D., Cowden, R., Karodia, A.M. (2014). The Impact of Training and Development on Employee Performance: A Case Study of Ascon Consulting. Singaporean Journal of Business Economics and Management Studies. (3), pp. 72-105.

[12] Law on Mongolian SME. 2007. Ulaanbaatar.

[13] Lee, K. W. (2016). Skills Training by Small and Medium-Sized Enterprises: Innovative Casesand the Consortium Approach in the Republic of Korea. Asian Development Bank Institute.

[14] Lkhagvasuren, T., Xuexi, H.,(2014). Analysis of the Returns of Small and Medium-sized Enterprises in Mongolia. Journal of Finance and Accounting. http://www. sciencepublishinggroup.com $/ \mathrm{j} / \mathrm{jfa}$.

[15] Mazzarol, T. (2003). A Model of Small Business HR Growth Management. International Journalof Entrepreneurial Behavior \& Research. (9) 1, pp. 27-49.

[16] Orpen, B., Strategic HRM: Research and Practice in Ireland, Chapter: HRM in Small and Medium Sized Enterprises.pp.153-169.

[17] Pürevdagva, Kh., Batkhürel, G. (2015). Human Resource Management. Ulaanbaatar.

[18] Susomrith, P., Coetzer, A.J. (2013). Access to Training and Development in Small and Medium-sized Enterprises: Employee's perspectives.

[20] Tahir, A., Sajjad, S. (2013). Assessing the Impact of Training on Employees' Performance in Commercial Banks in Urban Lahore. The Lahore Journal of Business. pp. 95-109.

[21] Bank of Mongolia. (2017). Small and Medium Enterprises' Development and Financial access.Ulaanbaatar.

[22] Tsetsegmaa, Ts., 2014. Human Resource Management (Theory andPractice), Ulaanbaatar.

[23] Vinesh, (2014). Role of Training \& Development in an Organizational Development. International Journal of Management and International Business Studies. (4)2, pp. 213220. http://www.ripublication.com. 